\title{
Simulation and measurement of air quality in the traffic congestion area
}

\author{
Shin $\mathrm{Yu}^{1}$, Chang Tang Chang ${ }^{1}$ and Chih Ming Ma ${ }^{2^{*}}$ (D)
}

\begin{abstract}
The traffic congestion in the Hsuehshan tunnel and at the Toucheng interchange has led to traffic-related air pollution with increasing concern. To ensure the authenticity of our simulation, the concentration of the last $150 \mathrm{~m}$ in Hsuehshan tunnel was simulated using the computational fluid dynamics fluid model. The air quality at the Toucheng interchange along a 2 km length highway was simulated using the California Line Source Dispersion Model. The differences in air quality between rush hours and normal traffic conditions were also investigated. An unmanned aerial vehicle (UAV) with installed $\mathrm{PM}_{2.5}$ sensors was developed to obtain the three-dimensional distribution of pollutants. On different roads, during the weekend, the concentrations of pollutants such as $\mathrm{SOx}, \mathrm{CO}, \mathrm{NO}$, and $\mathrm{PM}_{2.5}$ were observed to be in the range of $0.003-0.008,7.5-15$, $1.5-2.5 \mathrm{ppm}$, and $40-80 \mathrm{\mu g} \mathrm{m}^{-3}$, respectively. On weekdays, the vehicle speed and the natural wind were $60 \mathrm{~km} \mathrm{~h}^{-1}$ and 2.0 $\mathrm{m} \mathrm{s}^{-1}$, respectively. On weekdays, the $\mathrm{SO}, \mathrm{CO}, \mathrm{NO}$, and $\mathrm{PM}_{2.5}$ concentrations were found to be in the range of $0.002-0.003$, 3-9, 0.7-1.8 ppm, and 35-50 $\mathrm{mg} \mathrm{m}^{-3}$, respectively. The UAV was used to verify that the $\mathrm{PM}_{2.5}$ concentrations of vertical changes at heights of 9.0, 7.0, 5.0, and $3.0 \mathrm{~m}$ were $45-48,30-35,25-30$, and $50-52 \mu^{-3} \mathrm{~m}^{-3}$, respectively. In addition, the predicted $\mathrm{PM}_{2.5}$ concentrations were $40-45,25-30,45-48$, and $45-50 \mathrm{\mu g} \mathrm{m}^{-3}$ on weekdays. These results provide a reference model for environmental impact assessments of long tunnels and traffic jam-prone areas. These models and data are useful for transportation planners in the context of creating traffic management plans.
\end{abstract}

Keywords: Traffic emissions, CALINE4, CFD, Highway, Unmanned aerial vehicle

\section{Introduction}

Indoor and outdoor air quality is a hot research topic and a major determinant of human health. More attention has been given to indoor air quality in recent years, as it has more significant effects on respiratory disease and cardiovascular health than outdoor air pollution [1]. According to previous studies, almost $90 \%$ of our time is spent in enclosed areas (e.g., homes, schools, offices, transport, and meeting places) [2-6]. Many people are exposed to high concentrations of traffic contaminants when they drive in heavy traffic and spend time at places near roads that have a high amount of traffic, especially if the location is downwind of the road [7, 8]. Air pollutants (e.g., volatile organic compounds, nitrogen oxides,

\footnotetext{
* Correspondence: cmma@smc.edu.tw

${ }^{2}$ Department of Cosmetic Application and Management, St. Mary's Junior College of Medicine, Nursing and Management, Sanxing Township 266003, Taiwan

Full list of author information is available at the end of the article
}

and particulate matter) are complex and dynamic, and vehicle emissions have become the dominant source of air pollutants $[9,10]$. Campagnolo et al. [11] demonstrated that vehicle emission reductions have a strong impact on the effective control of human in-cabin exposure and improve the air quality in traffic environments. The increasing severity and duration of traffic congestion have the potential to increase pollutant emissions and degrade air quality, particularly near large roadways. Therefore, a study on air quality caused by vehicle emissions is necessary to help understand the effect of air pollution as a health risk to drivers.

There are several methods for modeling the dispersion of different pollutants emitted from a roadway reported in the literature [12, 13]. The Gauss dispersion California Line Sources Dispersion Model (CALINE4) treats emissions as a continuous line source, either without any adjustment or using a simple enhancement [14]. Dhyani and Sharma [15] pointed out that the CALINE4 requires relatively lower levels

(c) The Author(s). 2021 Open Access This article is licensed under a Creative Commons Attribution 4.0 International License, which permits use, sharing, adaptation, distribution and reproduction in any medium or format, as long as you give appropriate credit to the original author(s) and the source, provide a link to the Creative Commons licence, and indicate if changes were made. The images or other third party material in this article are included in the article's Creative Commons licence, unless indicated otherwise in a credit line to the material. If material is not included in the article's Creative Commons licence and your intended use is not permitted by statutory regulation or exceeds the permitted use, you will need to obtain permission directly from the copyright holder. To view a copy of this licence, visit http://creativecommons.org/licenses/by/4.0/. 
of expertise and comparatively fewer input data than other vehicular dispersion models. The computational fluid dynamics fluid model (CFD) is popularly used in environmental engineering [16, 17]. For example, Wang et al. [18] recommended the optimal deflect angle for tunnel ventilation using CFD. Qin et al. [19] recommended the numerical simulation of airborne $\mathrm{HCHO}$ pollution in vehicle cabins using CFD. Through CFD simulation, it can be an accurate prediction of air pollution flow properties and species transport [20-22]. The estimation of the airflow patterns and flows in tunnels and other complex structures was mathematically modeled by CFD [23]. To accurately predict the species transport and flow properties, governing flow equations were solved to simulate atmospheric turbulence [24]. In addition, unmanned aerial vehicles (UAVs) are commonly used in the military, agricultural surveillance, and transportation fields [25]. The UAV has flexibility and mobility to be used at metropolises or suburban areas. UAVs are low-cost technology and have application potential in various fields, including collecting detailed military, traffic volumes, and meteorological data [26, 27]. A UAV with sensors was a new application method to measure the threedimensional spatial distribution of air pollutants [28].

The rapid development of tourism in Yilan County, Taiwan, has led to traffic-related air pollution with increasing concern. The $12.9 \mathrm{~km}$ Hsuehshan Tunnel is located between Taipei and Yilan. The Hsuehshan Tunnel provides convenient travel but simultaneously causes air pollution due to poor dispersion conditions compared to an ordinary road [29]. The motivation of this study was to use the CALINE4 and CFD to investigate the air quality in the traffic congestion area and provide a reference method that can be applied to estimate the health risks to drivers due to exposure as well as obtain useful data for stakeholders. The first objective was to simulate the concentrations of the last $150 \mathrm{~m}$ in the Hsuehshan tunnel using CFD. The second objective was to predict the air quality at the Toucheng interchange over a $2 \mathrm{~km}$ length of the highway using CALINE4 and obtain the threedimensional distribution of pollutants using a UAV for a validated air quality forecast. Many countries have fewer than three monitoring stations/million inhabitants, and their location is often restricted. If these models can predict air quality, they would help reduce the enormous workload involved in on-site measurement. The results of this study could provide stakeholders with information on the air quality inside long tunnels or near tunnel exits/inlets and help them draw up useful traffic management plans.

\section{Materials and methods}

\section{Study region and data collection}

In this study, the air quality was assessed along a highway at different points, i.e., the last $150 \mathrm{~m}$ in the Hsuehshan tunnel and over a $2 \mathrm{~km}$ length of the highway at the Toucheng interchange (as shown Fig. 1). Near the
Toucheng interchange, there are many recreational landmarks (e.g., hot springs and dolphin watching) and tourist attractions with more than 1 hundred hotels, and many fresh seafood restaurants. Nevertheless, the level of bus ridership in Yilan County is lower than that in other metropoles in Taiwan. Therefore, traffic congestion in the Hsuehshan tunnel and the Toucheng interchange has long been a characteristically obvious reference.

The traffic volume data were sourced from the databank of the Ministry of Transportation and Communications (MOTC) and Taiwan Area National Expressway Engineering Bureau (TANEEB). Basic information on the Hsuehshan tunnel and Toucheng interchange was obtained from the databank of TANEEB. Due to safe driving considerations, vehicle information at 5-min intervals can be collected using cameras taking images of vehicle discs/hubcaps in the Hsuehshan tunnel. The information contains the total number of heavy-duty vehicles (e.g., bus) and light-duty vehicles (e.g., sedan and van). According to the data in the databank of MOTC and our previous research, the number of vehicles in 2019 was two times higher than that in 2009 [29]. The emission rate of pollutants was sourced from the Taiwan Emission Data System (TEDS) of Environmental Protection Administration (EPA). The weather information was obtained from operational numerical forecasting models. The meteorological data were summarized from the Toucheng station of the Central Weather Bureau. The coordinates and height of the monitoring site are 121.81 and 24.85 and $6.0 \mathrm{~m}$, respectively.

\section{Model design and establishment}

A modified CALINE4 was used to predict local traffic emissions within $2 \mathrm{~km}$ for four traffic-related pollutants (CO, NO, $\mathrm{SO}_{2}$, and $\mathrm{PM}_{2.5}$ ) based on the Gaussian diffusion model. The data that the simulation software needs to enter are road type pollutants, emission rate, receptors, and meteorology (e.g., wind direction, wind speed, atmospheric stability, and mixing height) [15], as shown in Table 1. The grid area was established within $200 \times$ $200 \mathrm{~m}$ along with the line source. The blue points are receptor points, and the red star is monitoring site, as shown in Fig. 1. All of the receptor points are extended from the center. In addition, each interval distance is $200 \mathrm{~m}$ to compare the pollutant concentration at each receptor point. The simulated results with CALINE4 were also compared with monitored data during holidays and weekdays in March, 2019.

In this paper, the $\mathrm{CO}, \mathrm{NO}, \mathrm{SO}_{2}$, and $\mathrm{PM}_{2.5}$ pollutant concentrations were simulated at the tunnel exit during the traffic jam period and normal period, and the relationship between air quality and traffic volume was established. ANSYS Fluent 7.0 software has well-validated physical and 

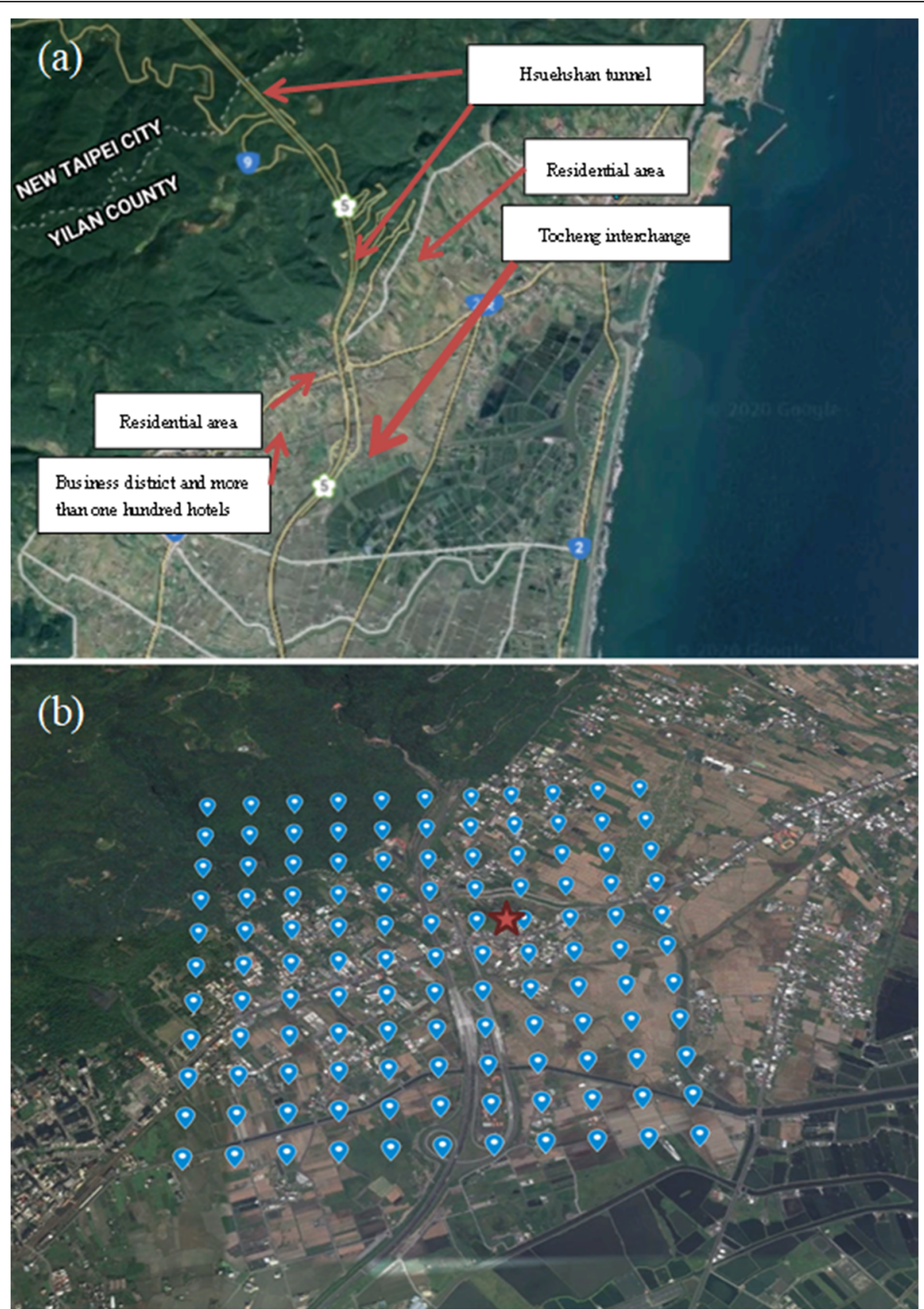

Fig. 1 a Study region $\mathbf{b}$ Simulation points of CALINE4

chemical modeling capabilities, accurate results across the widest range of CFD, and multiphysics applications. ANSYS Fluent 7.0 is the numerical simulation software for Windows Version. The step is the geometric description, mesh, selecting master equation and boundary conditions, and numerical solution [19]. In addition, ANSYS Fluent software has very good performance optimization capabilities and can predict flow, turbulence, heat transfer, and reactions for industrial applications. Therefore, this software was used in this study for the air quality simulations. A numerical analysis was used to assess the air quality of tunnels in different conditions to further improve the associated ventilation equipment, pollution prevention, and control strategies. In this study, we used the $\mathrm{k}-\varepsilon$ turbulence model as $[20,22,23]$ :

$$
\begin{aligned}
\frac{D K}{D t}= & \frac{\partial}{\partial X j}\left\{\left(v+\frac{v t}{\sigma_{k}}\right) \frac{\partial K}{\partial t}\right\} \\
& +v t\left(\frac{\partial U j}{\partial X i}+\frac{\partial U i}{\partial X j}\right) \frac{\partial U i}{\partial X j}+\beta g \frac{v t}{\sigma_{\theta}} \frac{\partial \theta}{\partial X i}-\varepsilon
\end{aligned}
$$


Table 1 Input parameters in CALINE4

\begin{tabular}{|c|c|c|}
\hline Parameters & Values/units & Source \\
\hline Traffic Data & $24 \mathrm{~h}$ & On-site video recording/MOTC \\
\hline Weighted emission factor & g mile $e^{-1}$ & TEDS \\
\hline \multicolumn{3}{|l|}{ Road geometry } \\
\hline $\begin{array}{l}\text { Mixing zone width (way width }+3 m \text { on both } \\
\text { sides) }\end{array}$ & $21+6=27 m$ & Measurement \\
\hline Road type & $\begin{array}{l}\text { National highway NO.5- } \\
\text { Bridge } \\
\text { Provincial road NO.2- Ground } \\
\text { Provincial road NO.9- Ground }\end{array}$ & Google MAP \\
\hline \multicolumn{3}{|l|}{ Meteorological data } \\
\hline Wind speed & $\mathrm{ms}^{-1}$ & Central Weather Bureau \\
\hline Temperature & ${ }^{\circ} \mathrm{C}$ & \\
\hline Wind direction & Degree $\left(^{\circ}\right)$ & \\
\hline Mixing height & $\mathrm{m}$ & \\
\hline Stability class & $A, B, C, D, E, F, G$ & \\
\hline Background pollutant & None & \\
\hline Monitored & $\begin{array}{l}\mathrm{PM}_{2.5}\left(\mu \mathrm{g} \mathrm{m}^{-3}\right) \\
\mathrm{SO}_{2}(\mathrm{ppb}) \\
\mathrm{NO}(\mathrm{ppb}) \\
\mathrm{CO}(\mathrm{ppm})\end{array}$ & $\begin{array}{l}\text { On-site measurement ( } 5 \mathrm{~m} \text { away from the border of the } \\
\text { road) }\end{array}$ \\
\hline
\end{tabular}

where $\mathrm{K}$ is the thermal diffusivity $\left(\mathrm{m}^{2} \mathrm{~s}^{-1}\right), \mathrm{Xi}$ is Cartesian coordinates, $\mathrm{V}$ is the kinematic viscosity $\left(\mathrm{m}^{2} \mathrm{~s}^{-1}\right)$ of air, $\beta$ is the volumetric coefficient of expansion $\left(\mathrm{K}^{-1}\right), \varepsilon$ is the dissipation rate, $\mathrm{Ui}$ is instantaneous velocity $(\mathrm{m}$ $\mathrm{s}^{-1}$ ) component $\mathrm{i}$, and $\theta$ is the instantaneous temperature difference.

In addition, an in-tunnel simulation was performed using CFD, including (i) a pollutant concentration simulation during holiday and nonholiday periods; (ii) nitrogen oxides, carbon monoxide, and particulate matter concentration prediction near the exit of Toucheng tunnel; and (iii) a flow field condition estimation in the tunnel. The geometry was created using the real tunnel specifications and vehicle sizes, which were applied as the differential and integral terms in the fluid dynamics' fundamental equations, including time/space variables and physical variables. CFD calculation processes include the analysis of balance and fluid dynamics equations, which are the momentum balance, mass balance, and energy balance equations. The governing equations are listed as follows [20, 22, 23]:

Momentum Equation

$$
\begin{aligned}
\frac{\partial U i}{\partial t}+\frac{\partial U i U}{\partial X j}= & -\frac{1}{\rho} \frac{\partial P}{\partial X i} \\
& +\frac{\partial}{\partial X i}\left\{v\left(\frac{\partial U i}{\partial X j}+\frac{\partial U j}{\partial X i}\right)\right\}-\beta g \theta
\end{aligned}
$$

Conservation Equation

$$
\frac{\partial U i}{\partial X j}=0
$$

\section{Conservation of Energy}

$$
\frac{\partial \theta}{\partial t}+\frac{\partial \theta U j}{\partial X j}=\frac{\partial}{\partial X j}\left(K \frac{\partial \theta}{\partial X j}\right)+H
$$

Conservation of Contaminant

$$
\frac{\partial C}{\partial t}+\frac{\partial C U j}{\partial X j}=\frac{\partial}{\partial X j}\left(D \frac{\partial C}{\partial X j}\right)+S
$$

where $\mathrm{C}$ is the instantaneous concentration of passive contaminant $\left(\mathrm{kg} \mathrm{m}^{-3}\right), \mathrm{D}$ is the molecular diffusion coefficient $\left(\mathrm{m}^{2} \mathrm{~s}^{-1}\right), \mathrm{g}$ is the gravitational acceleration $(\mathrm{m}$ $\mathrm{s}^{-2}$ ), $\mathrm{P}$ is the instantaneous static pressure difference ( $\mathrm{N}$ $\left.\mathrm{m}^{-2}\right), \rho$ is the density $\left(\mathrm{kg} \mathrm{m}^{-3}\right)$ of air, $\mathrm{H}$ is the volume heat source generation rate $\left(\mathrm{kW} \mathrm{m}^{-3}\right), \mathrm{S}$ is the flow rate of contaminant generation source $\left(\mathrm{m}^{3} \mathrm{~s}^{-1}\right)$, and $\mathrm{k}$ is the kinetic energy $\left(\mathrm{kg} \mathrm{m}^{2} \mathrm{~s}^{-2}\right)$.

The temporal and spatial variables and the physical variables had to be discretized to replace these integral or differential terms with discrete algebraic forms. Discrete spatial variables corresponding to the solution domain were divided into a series of lattices, called the unit body or control body (mesh, cell, control volume). The grid corresponding to the lattice boundary is called the grid. In addition, the intersection of the grid is called the grid point. Similar to algebraic methods, differential methods are also used to generate grids, as used by 
Thompson et al. [30]. For differential methods, discrete physical variables are often defined at grid points. The differential operation on a grid point can be approximated as the algebraic relationship between the physical point on the grid point, the adjacent grid points, and the grid point coordinates. The numerical method, in this case, is called the finite difference method. In this study, the mesh type was a tetrahedron, and the total grid number was approximately 2.9 million.

Bhautmage and Gokhale [24] pointed out that modeling the shape of the automobile is complex. Therefore, simplified vehicle body shapes of average dimensions were built. As shown in Fig. 2, the vehicle objects were categorized as a bus, a sedan, a van, and a small truck, which have variations in size, architecture, and pollution discharge rate. The aspect ratio of the vehicle models was $4.5 \times 2 \times 2 \mathrm{~m}$ for the van, $4.5 \times 1.5 \times 1.5 \mathrm{~m}$ for the sedan, $8 \times 2.5 \times 3 \mathrm{~m}$ for the bus, and $5.5 \times 1.5 \times 2.5 \mathrm{~m}$ for the truck. The exhaust pipe diameter for a bus and a van was set to $6 \mathrm{~cm}$. In addition, the exhaust diameter of the sedan and small truck was $4 \mathrm{~cm}$. The exhaust pipe was positioned behind the sedan's right bottom corner (which is $0.2 \mathrm{~m}$ above the road surface), van (which is $0.4 \mathrm{~m}$ high), and truck (which is $0.3 \mathrm{~m}$ high) in the realtime data for model validation. $0.5 \mathrm{~m}$ high at the bottom in the middle of the bus. An exhaust pipe in the vehicle was defined as an emission source. The effect of the shape on velocity estimation was neglected due to the minor variation in the physical properties between the small truck and van for further analysis.

\section{Measurement and data analysis}

In the CFD simulation and calculation, the monitored concentration data were sourced from the EPA. In the CALINE4, the blue points are receptor points, and the red star is the monitoring site $(5 \mathrm{~m}$ away from the border of the road), as shown in Fig. 1b. This study measured the $\mathrm{CO}, \mathrm{NO}, \mathrm{SO}_{2}$, and $\mathrm{PM}_{2.5}$ concentrations near the Toucheng intersection. The sampling site address is No. 6, Sec. 1, Qingyun Rd., Toucheng Township, Yilan County 261, Taiwan. The data were collected every hour from 18th March to 28th April in 2019. $\mathrm{PM}_{2.5}$ sampling was performed using the atmospheric particulate matter analysis high volume sampling method. Atmospheric particulates were collected on quartz filter paper after sampling. A UAV with ambient pollutant sensors is emerging as a new means to produce three-dimensional observations of ambient air pollutants, as shown in Fig. 3. The objective of this study was to validate air quality forecasting by UAVs with $\mathrm{PM}_{2.5}$ sensors. $\mathrm{PM}_{2.5}$ was measured only since the bias and variation of the other sensors are too large. The sensors are two types, one type is $1.45 \mathrm{~kg}$, and the other type is $100 \mathrm{~g}$. The sensors were made in two companies. All of the flying missions are all along the highway. The UAV can remain at the same point for $20 \mathrm{~s}$ and the time interval of measuring is
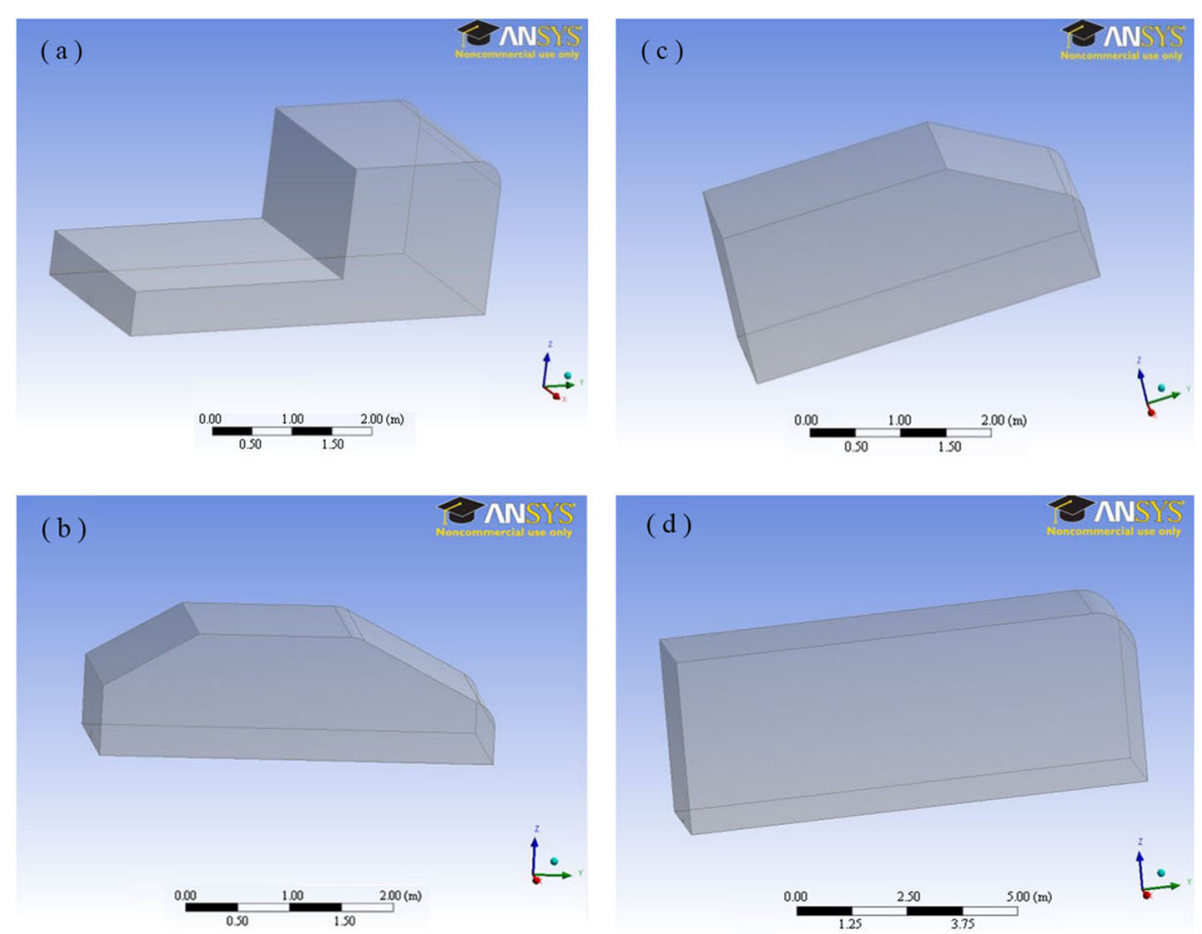

Fig. 2 Geometry of vehicles (a) small truck; b sedan; c van; d bus 

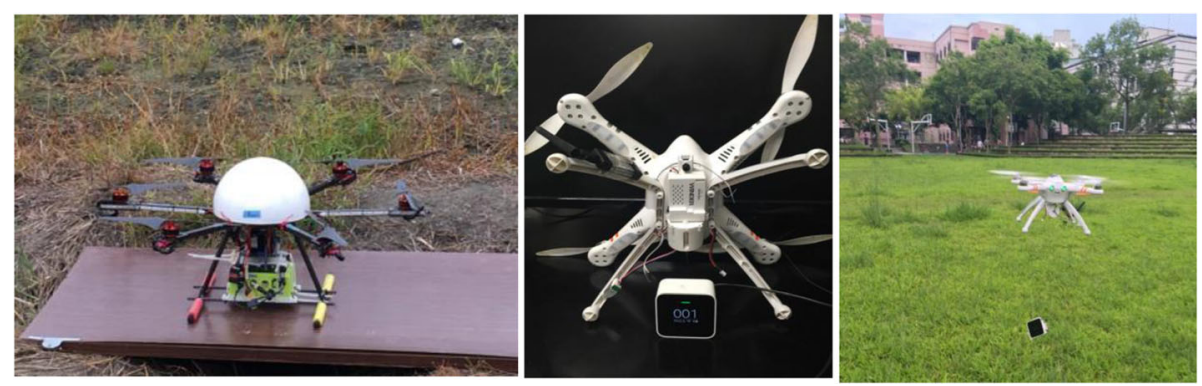

Fig. $3 \mathrm{PM}_{2.5}$ sensors of UAV

a second. In addition, to ensure accurate measurement values, the sensor was used to collect sampling site data with EPA pollutant station data (in Yilan Fushing Junior High School) to calibrate the sensor. To collect threedimensional air pollutant concentration data, the experiment was designed around a $2 \times 2 \mathrm{~km}$ area. In addition, the points have the same coordinates as the simulation, and data were collected at heights of $3,5,7$, and $9 \mathrm{~m}$ to monitor the vertical profile of air pollutants.

Normal mean square error (NMSE) is the standard deviation of the residuals (prediction errors) and a measure of how to spread out these residuals [14]. It is traditionally used in climatology, forecasting, and regression analyses to verify experimental results. The fractional bias (FB) is a measure of the correlation between averages of predicted and observed values. The FB is based on the averages of the predicted and observed concentrations (macrostatistics) rather than a datum-by-datum comparison (microstatistics) [14]. In this study, the statistical performance of the CALINE4 was validated using NMSE and FB.

\section{Results and discussion}

\section{Vehicle volume and vehicles emission rate}

The road between Shihting Interchange and Toucheng Interchange prohibits the carriage of dangerous goods in both directions, including long, wide, high, and overweight vehicles. Small cars and buses can drive on the road between Shihting Interchange and Toucheng Interchange. Small cars include small passenger cars, small trucks, and small special passenger vehicles. Vehicle emission rates change at different speeds. Information about emission rates was created from TEDS. The particulate pollutant ratio sourced from TEDS for Toucheng is shown in Fig. 4a. Linear pollutants accounted for approximately $48.4 \%$. Accounting for the largest number, the diesel truck represents $27.0 \%$. The contributions of restrained dust and diesel small truck emissions were 12.3 and $4.9 \%$, respectively. The rest of the pollution sources from the area were commercial (4.2\%) and agricultural burning (26.3\%). The data were sourced from TEDS; the emission rates of buses, vans, trucks, and sedans for all kinds of pollutants are shown in Fig. 3. It also shows that vehicle emissions have a strong impact on the dispersion of air pollutants, such as $\mathrm{CO}$ and NOx, near Toucheng.

The Hsuehshan tunnel is one of the longest tunnels in the world. The road connects Taipei through New Taipei to Yilan County and shortens the journey from 2 $\mathrm{h}$ to just half an hour. Most frequently, this trip is made by car or by public transportation (though there are only a few services) through Hsuehshan Tunnel and Highway No. 5. As a result, the traffic through the tunnel is severely congested during the traffic jam period, increasing the travel time from $30 \mathrm{~min}$ up to $2 \mathrm{~h}$. The alternative method is a winding shoreline highway, or an equally dangerous mountain pass, both of which take much longer and are more dangerous because of their cliff-side locations. The data from the databank and monitoring system of MOTC regarding the traffic volume are shown in Fig. 4b and c. The average traffic volume was approximately 33,000 passenger car units (PCUs) $\mathrm{d}^{-1}$ on the weekend and 1800-2000 $\mathrm{PCU} \mathrm{h}^{-1}$ during rush hour. It also indicated that the maximum was more than 35,000 PCU d ${ }^{-1}$ on the weekend. In addition, the tunnel standard of pollutants is shown in Table 2 .

In this study, the emission factor with different vehicle speeds was used in Fluent software from TEDS. The CO, $\mathrm{NO}, \mathrm{SO}_{2}$, and $\mathrm{PM}_{2.5}$ pollutant emission rates changed when the vehicle speed changed. For example, the $\mathrm{CO}$ emission rate decreased with increasing traffic speed, especially from the exhaust of vans and buses, as shown in Fig. 4; with the increase of mean vehicle speed, vehicle emissions of a comprehensive factor gradually decreased. In this study, the vehicle speeds ranged from 20 to 100 $\mathrm{km} \mathrm{h}^{-1}$. In addition, the $\mathrm{SO}_{2}$ emission rate was lower than before because of lower gasoline sulfur content. The vehicle with the lowest emission rate was the sedan [31, 32]. The $\mathrm{SO}_{2}$ emission rate increased with increasing mean vehicle speed when the vehicle speed was below $50 \mathrm{~km} \mathrm{~h}^{-1}$. In contrast, the emission rate decreased with increasing mean vehicle speed when the vehicle speed was above 60 $\mathrm{km} \mathrm{h}^{-1}$ since diesel engines are used in van. In addition, diesel engines are also used in buses and trucks in similar 


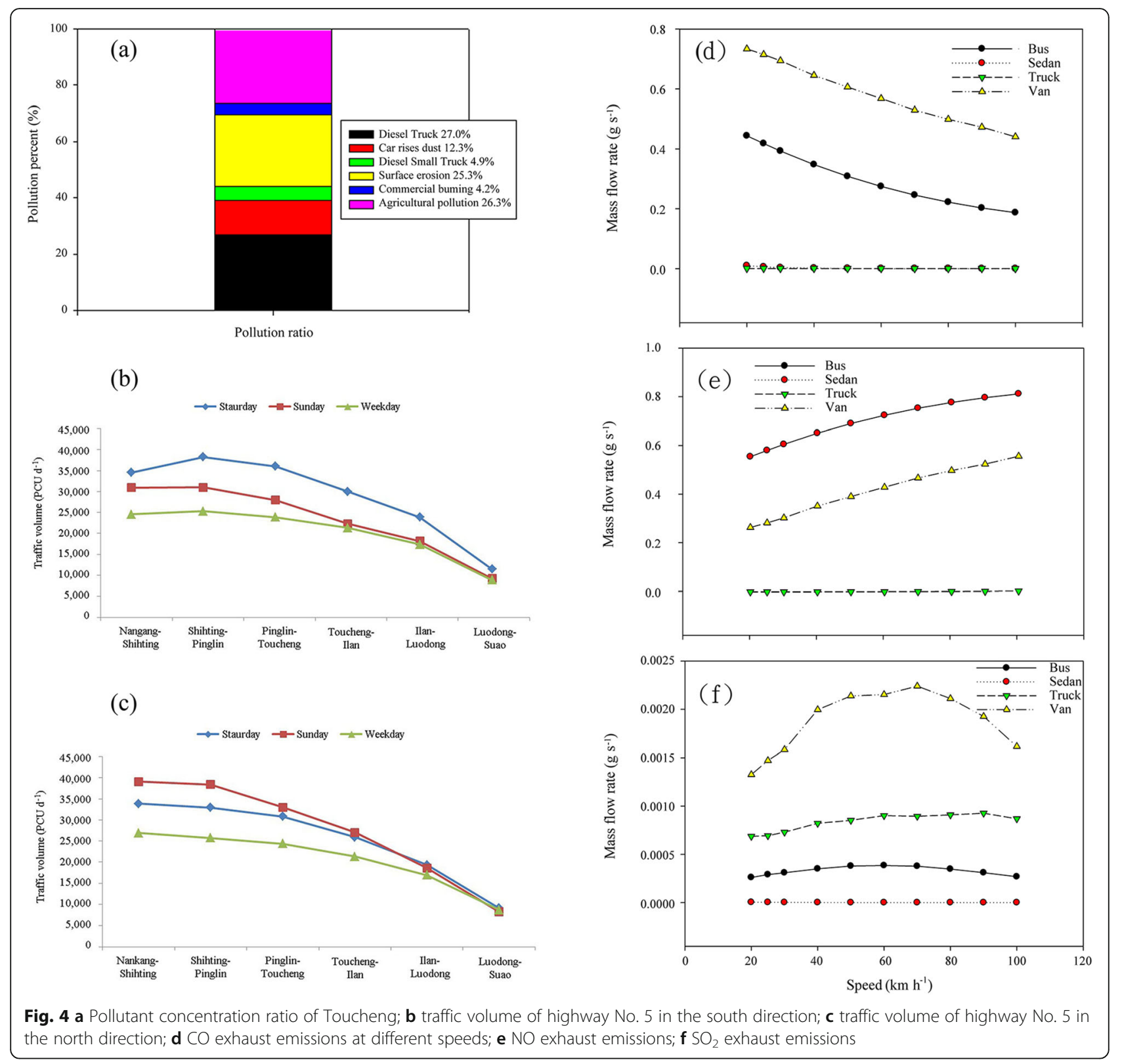

emission patterns, although the emission rate pattern is not obvious due to the small PCU.

\section{Concentrations simulated in the Hsuehshan tunnel}

Air pollutant concentrations of the last $150 \mathrm{~m}$ in the $12.9 \mathrm{~km}$ Hsuehshan tunnel were simulated by CFD. The wind speed is $3.5 \mathrm{~m} \mathrm{~s}^{-1}$, and the vehicle speed is $40 \mathrm{~km}$ $\mathrm{h}^{-1}$ when the fan is opened in the tunnel. The wind direction flows from the tunnel inlet in the direction of the vehicle. On the weekend, the results show that pollutant concentrations were mainly distributed in the tunnel outlet. As shown in Fig. 5, the $\mathrm{SO}_{2}, \mathrm{CO}, \mathrm{NO}$, and $\mathrm{PM}_{2.5}$ hourly concentrations ranged from 0.001 to $0.003,4.5$ to 9.0, 0.7 to $1.8 \mathrm{ppm}$, and 40 to $60 \mu \mathrm{g} \mathrm{m}^{-3}$, respectively.

Table 2 The air quality standard of tunnel

\begin{tabular}{llllllll}
\hline & Averaging period & England & Norway & Australia & USA & Japan & Taiwan \\
\hline $\mathrm{CO}(\mathrm{ppm})$ & $15 \mathrm{~min}$ & 200 & 200 & 100 & 120 & 100 & 75 \\
$\mathrm{NO}(\mathrm{ppm})$ & $1 \mathrm{~h}$ & 35 & 15 & - & 1.5 & -10 & 25 \\
$\mathrm{NO}_{2}(\mathrm{ppm})$ & $1 \mathrm{~h}$ & 5 & 1.5 & - & - & - \\
\hline
\end{tabular}




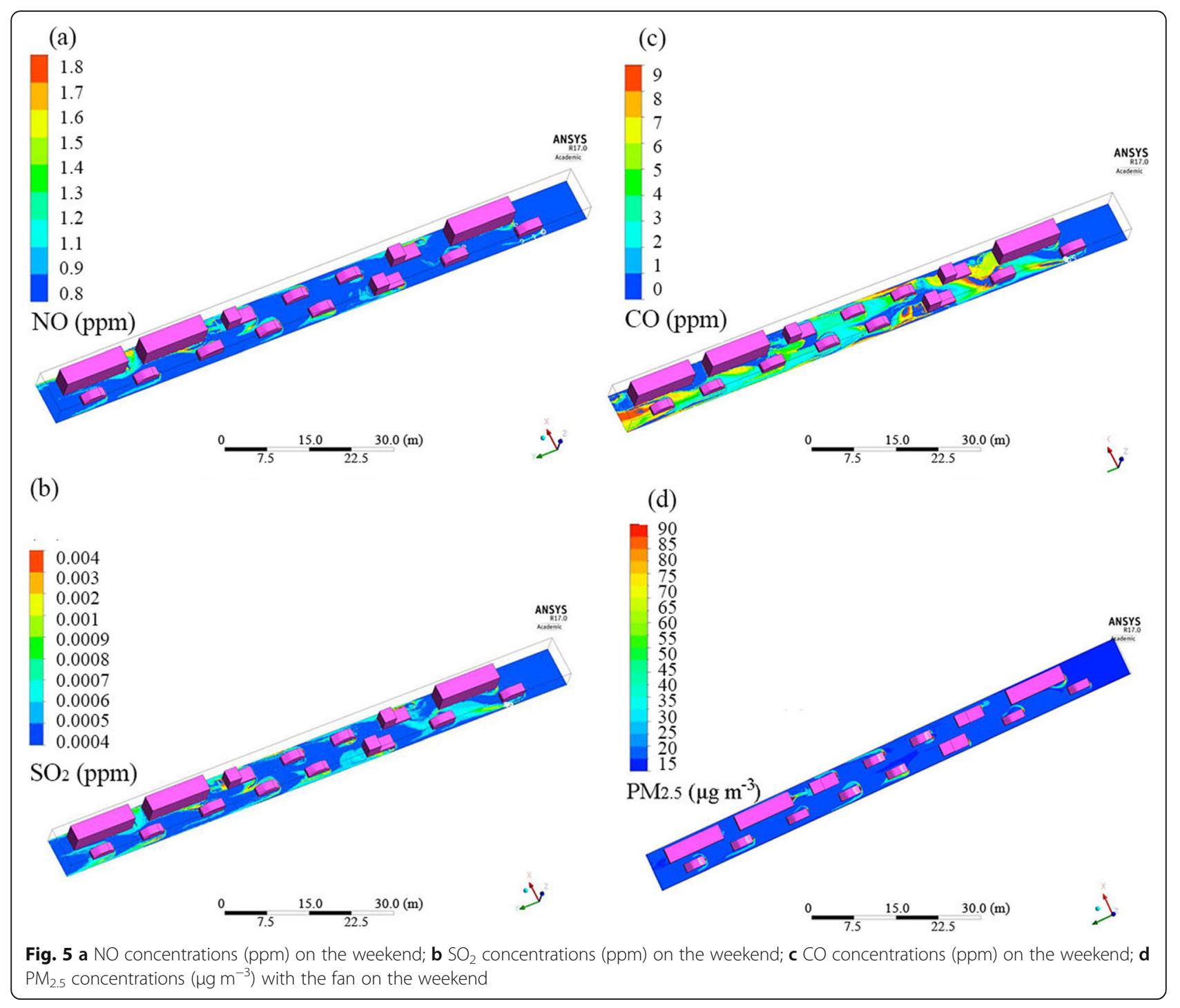

Both heavy-duty and light-duty types of vehicles emit large amounts of $\mathrm{PM}_{2.5}, \mathrm{CO}$, and $\mathrm{NO}$ and affect the tunnel's air quality. The pollutant emission factor of heavyduty vehicles is larger than that of light-duty vehicles. However, the vehicle number of heavy-duty vehicles is smaller than that of light-duty vehicles. The total emission rate of light-duty vehicles is smaller than that of heavy-duty vehicles. According to our previous study and the databank of MOTC, traffic volume during nonrush hours on weekends can be approximately $60 \%$ higher than that during non-rush hours on weekdays [29]. Therefore, traffic volume on the weekend could be regarded as rush hour, and on the weekday, it could be regarded as non-rush hours.

On weekdays, the pollutant concentrations are mainly distributed in the tunnel outlet. In addition, the $\mathrm{SO}_{2}$, $\mathrm{CO}, \mathrm{NO}$, and $\mathrm{PM}_{2.5}$ concentrations ranged from 0.001 to $0.002,2$ to $6,0.36$ to $1.08 \mathrm{ppm}$, and 20 to $55 \mu \mathrm{g} \mathrm{m}^{-3}$, respectively, at ambient temperatures of 23 to $25^{\circ} \mathrm{C}$, as shown in Fig. 6. From the simulation results, it was found that the concentration of various pollutants in the tunnel increases with a higher number of vehicles. The concentration of various pollutants becomes higher in the tunnel when the number of vehicles entering the tunnel increases. Thus, it is recommended to control the flow of vehicles within $4000 \mathrm{~h}^{-1}$ to control the $\mathrm{CO}, \mathrm{NO}$, and $\mathrm{PM}_{2.5}$ concentrations to meet the air quality standards.

\section{Concentrations simulated at the Toucheng intersection}

In this section, the comparison with modeled pollutants concentration in different height level is discussed. In this work, the air quality at the Toucheng interchange along a $2 \mathrm{~km}$ length of the highway was simulated by CALINE4. To analyze the $\mathrm{PM}_{2.5}$ pollutants along the highway at different heights, both height and 


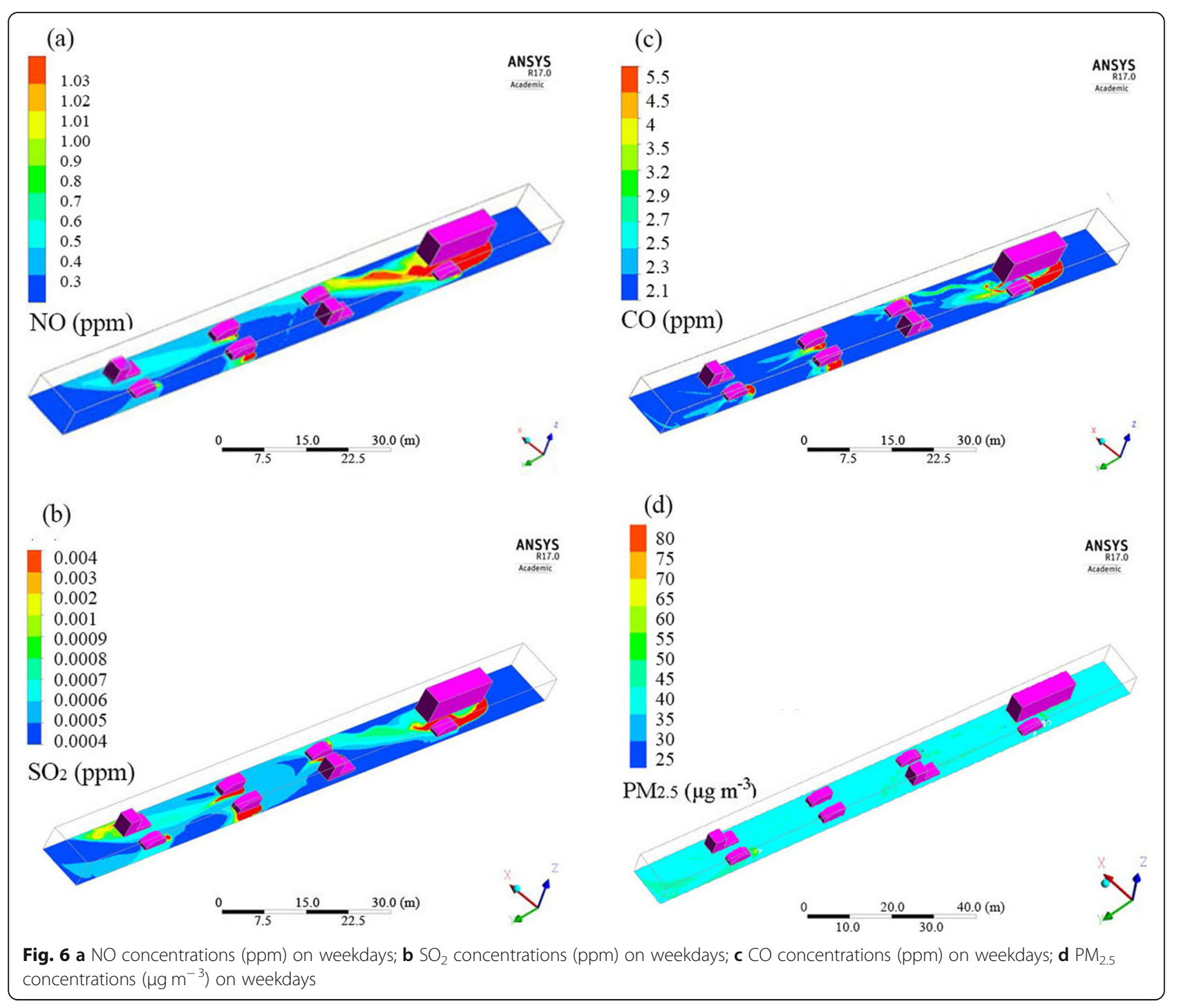

concentration data were used, as shown in Fig. 7. To evaluate the vertical concentration of particle matter along the highway, the highest concentration of $\mathrm{PM}_{2.5}$ was seen at $9 \mathrm{~m}$ at a level of $74 \mu \mathrm{g} \mathrm{m}^{-3}$, located at the intersection of tunnel exit, Toucheng intersection exit, and province freeway No. 2 . The levels at $7 \mathrm{~m}$ located at the intersection of tunnel exit, Toucheng intersection exit, and province freeway No. 2 were $50-58 \mu \mathrm{g} \mathrm{m}^{-3}$. The results show that the pollutant concentrations decreased with increasing distance from the highway and tunnel. The concentration of $\mathrm{PM}_{2.5}$ at $5 \mathrm{~m}$ was almost the same as that at $7 \mathrm{~m}$. However, the pollutants were stuck in the middle since the concentration spread from the center. In addition, the highest concentration was 54-58 $\mathrm{\mu g} \mathrm{m}^{-3}$. At $3 \mathrm{~m}$, the situation was different because the concentration increased again. The highest concentration, $58 \mu \mathrm{g} \mathrm{m}^{-3}$, was found at Provincial Road No. 9. The highest $\mathrm{PM}_{2.5}$ concentrations are located at
$9 \mathrm{~m}$ since the height of the highway is near $9 \mathrm{~m}$, and the $\mathrm{PM}_{2.5}$ concentrations are highest near the highway. The $\mathrm{PM}_{2.5}$ located at $3 \mathrm{~m}$ was slightly higher than that at 7$5 \mathrm{~m}$ since the data located at $3 \mathrm{~m}$ were affected by the vehicle's emissions on Provincial Road No. 9 with a height of $0 \mathrm{~m}$. The dispersion concentration became lower as the distance increased from where the traffic jam occurred. At $3 \mathrm{~m}$, the concentration becomes higher than at $7 \mathrm{~m}$ because human activity and large trucks raise particulate matter levels. In addition, the concentration of $\mathrm{CO}$ at $9 \mathrm{~m}$ was approximately $7 \mathrm{ppm}$, and the concentrations at 7.0, 5.0, 3.0, and $1.5 \mathrm{~m}$ were approximately $5.8,5.8,8.5$, and $10.0 \mathrm{ppm}$, respectively, as shown in Fig. 8.

\section{UAV monitoring}

It is difficult to measure the vertical pollutant concentration near a high level without UAVs. Therefore, it is 

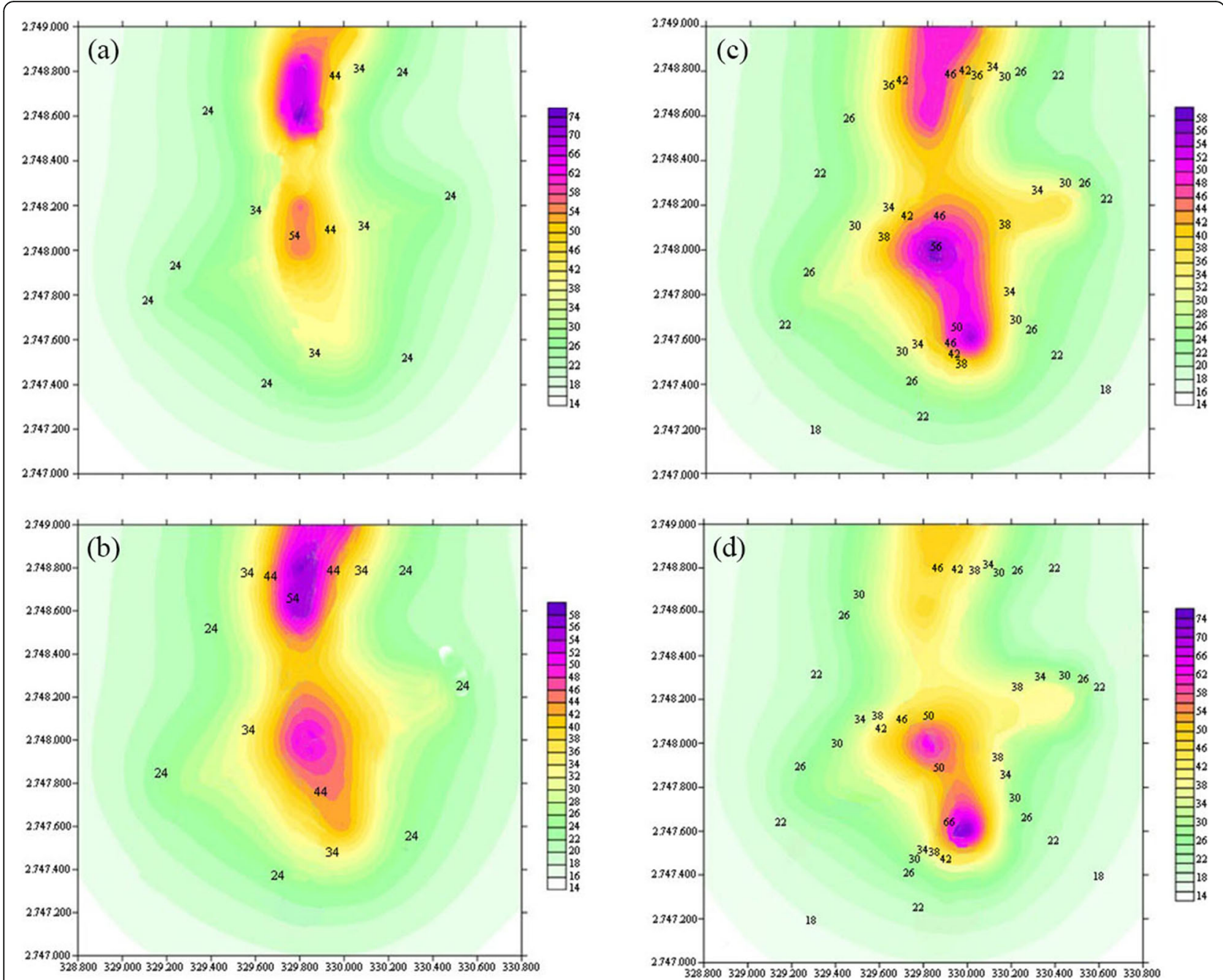

Fig. 7 Simulated hourly concentration of $\mathrm{PM}_{2.5}$ on the Toucheng highway intersection at (a) $9 \mathrm{~m} ; \mathbf{b} 7 \mathrm{~m} ; \mathbf{c} 5 \mathrm{~m}$; and $\mathbf{d} 3 \mathrm{~m}$. The $\mathrm{x}$-axis and $\mathrm{y}$-axis are Universal Transverse Mercator coordinate systems

good to verify the prediction data along the vertical direction with UAV data. To obtain the characteristics of the three-dimensional space distribution, a UAV with a sensor hanging system was used to monitor pollutants' levels. The vertical air quality distribution was monitored with UAV carrying sensors. Using the UAV, the air quality monitoring instruments are taken up and down vertically to obtain spatial distribution data. The rotor of UVA affects the measured values with the UAV carrying sensors. As shown in Fig. 9a, the relative correlation of the hanging length of the sensor goes to 0.85 $0.73,0.32$, and 0.09 at $1.5,1.0,0.5$, and $0.3 \mathrm{~m}$, respectively. In addition, the wind speed increases as the height increases. Therefore, positioning the sensor too high is dangerous. Therefore, the best hanging height was approximately $1.5 \mathrm{~m}$. As shown in Fig. 9b, the UAV $\mathrm{PM}_{2.5}$ monitoring was compared with the EPA station in Yilan Fushing Junior High School (the height is approximately
$14 \mathrm{~m})$, and the data for each hour were very close between them. However, UAV monitoring was also affected by weather conditions.

Figure 10 presents the concentration of $\mathrm{PM}_{2.5}$ with a $3 \mathrm{D}$ distribution. Generally, the concentration of $\mathrm{PM}_{2.5}$ decreased as the height increased, and the results were similar to those of another study [33]. Due to the minimal ground emission source, no difference in all flights was observed in the horizontal distribution. On weekday mornings, the $\mathrm{PM}_{2.5}$ concentrations was approximately $40-45 \mu \mathrm{g} \mathrm{m}^{-3}$ at $1.5 \mathrm{~m}$. The human activity caused the emissions of pollutants to accumulate $[34,35]$. The vehicle volume on the highway during the week days was lower than that on weekends, and the concentration decreased as the height increased. There is an incremental temperature in the air, while there is a rise in the solar energy and radiation levels. Until the early afternoon, there was a gradual increase in the concentration of the 

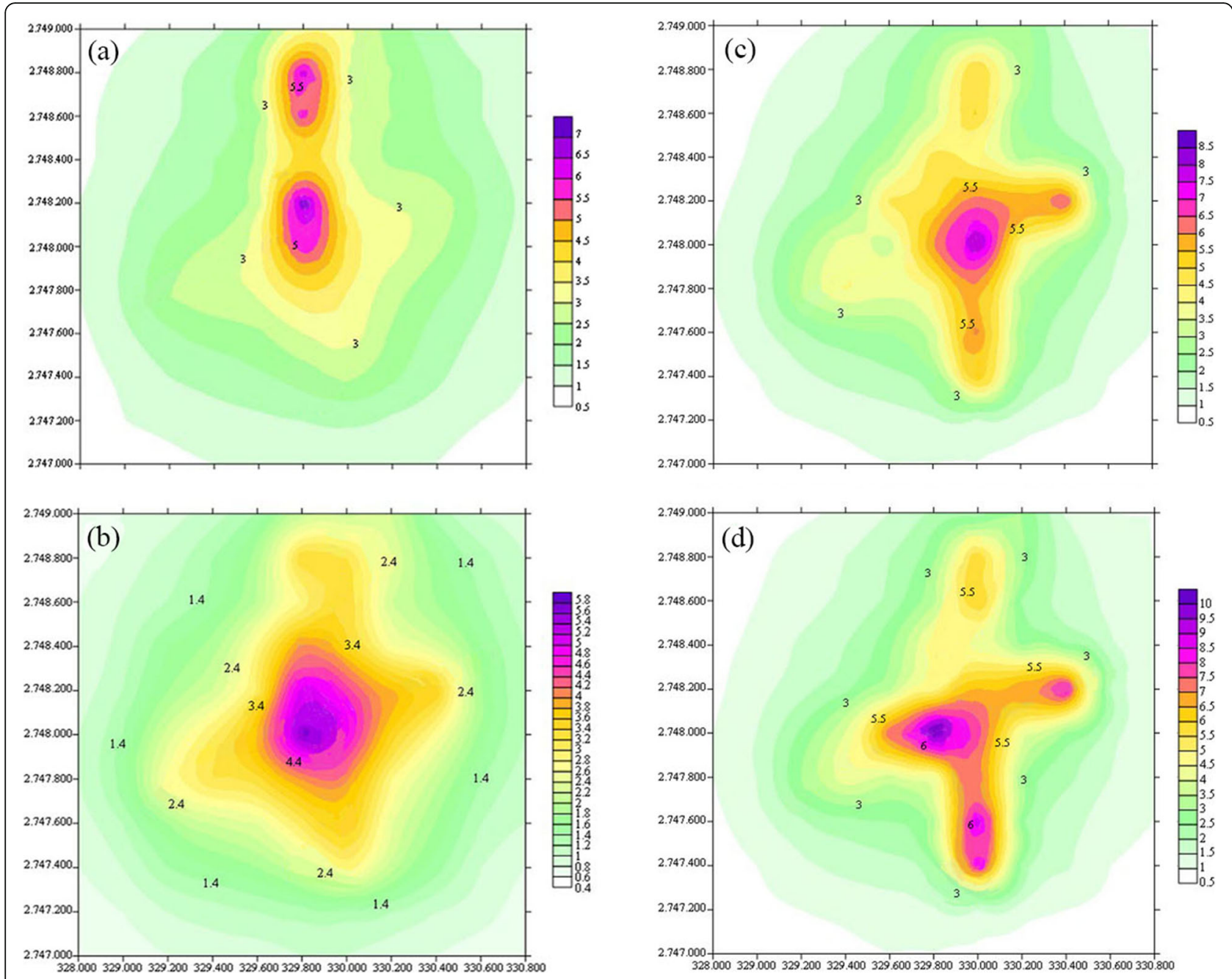

Fig. 8 Simulated hourly concentration of CO on the Toucheng highway intersection at (a) 9 m; b 7 m; c 5 m; and $\mathbf{d} 3 \mathrm{~m}$. The $x$-axis and $y$-ax are Universal Transverse Mercator coordinate systems

$\mathrm{PM}_{2.5}$ pollutants. This results in the highest energetic solar radiation peak with the earlier change in the $\mathrm{PM}_{2.5}$ concentrations. Therefore, the concentration became higher at night at approximately $45-50 \mu \mathrm{g} \mathrm{m}^{-3}$ at $1.5 \mathrm{~m}$ and lower at the level of 3-5 $\mathrm{m}$ during rush hour. The concentration increased in the highway at $9 \mathrm{~m}$. In addition, the peak was between 48 and $50 \mathrm{\mu g} \mathrm{m}^{-3}$. This is close to the gas analyzer monitoring data. On weekends, more vehicle exhaust pollutant emissions come from highways. Therefore, the concentration at $9 \mathrm{~m}$ in the afternoon was $45-50 \mu \mathrm{g} \mathrm{m}^{-3}$. The concentrations were approximately $30-35,25-30,30-35$, and $40-45 \mu \mathrm{g}$ $\mathrm{m}^{-3}$ at $3,5,7$, and $9 \mathrm{~m}$, respectively. The concentrations were approximately $45-48 \mu \mathrm{g} \mathrm{m}^{-3}$ at $9 \mathrm{~m}$ in the morning. The concentrations were approximately $25-30,15-$ 20 , and $12-15 \mu \mathrm{g} \mathrm{m}^{-3}$ at 3,5 , and $7 \mathrm{~m}$, respectively.

\section{Model sensitivity analysis}

The inputs for the CALINE4 package are roadway geometry, meteorological parameters, such as temperature and humidity, emission rate, traffic volume (in vehicles per hour), wind speed, wind direction and its standard deviation. In CALI NE4, the wind direction standard deviation (S) was calculated according to the Eq. (6) and it ranged from 0 to $20^{\circ}$.

$$
S=\sqrt{\frac{\sum_{i=1}^{n}\left(X_{i}=\bar{X}\right)^{2}}{n-1}}
$$

where $X_{i}$ is the wind direction, $\bar{X}$ is the average of wind direction, and $\mathrm{n}$ is the monitored number of wind direction. 

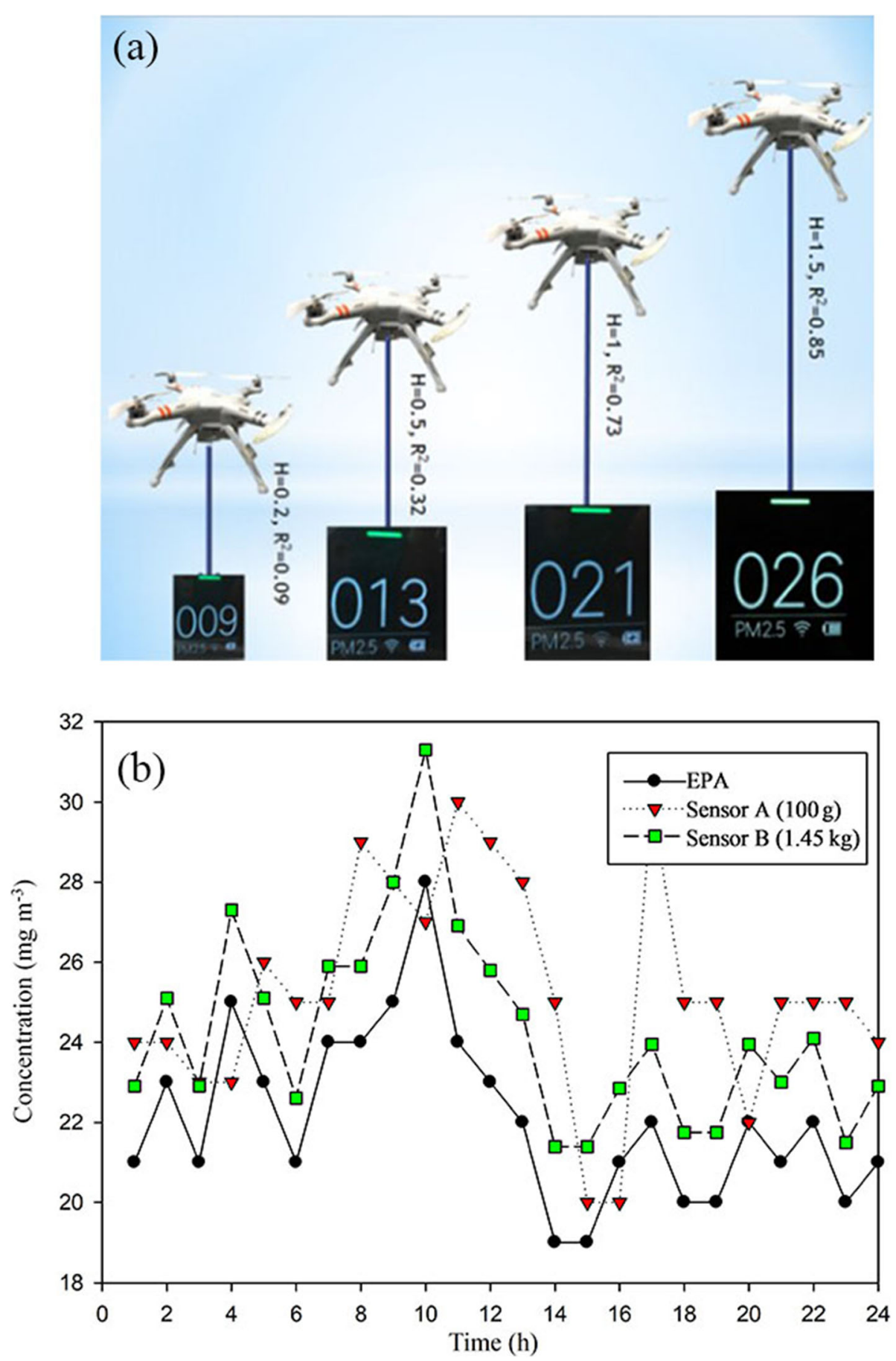

Fig. 9 a Hanging length with a sensor; $\mathbf{b}$ comparison of data from the UAV and EPA stations

The concentration rapidly dropped as the wind speed increased, especially at $0.5-1 \mathrm{~m} \mathrm{~s}^{-1}$, and the CO concentration changed from 10 to $50 \mathrm{ppm}$. The wind direction standard deviation is also important when the $S$ is more than $20^{\circ}$. The $\mathrm{CO}$ concentration tended to be moderate, and the standard deviation of the wind direction was $5^{0}$ at a $\mathrm{CO}$ concentration of approximately $120 \mathrm{ppb}$. The standard deviation of wind direction was more than $20^{\circ}$ when the concentration of $\mathrm{CO}$ remained at $50 \mathrm{ppb}$. At a high mixing layer height $(1000 \mathrm{~m})$, the concentration of CO was $1.4-2.5 \mathrm{ppb}$. At a lower mixing layer height $(500 \mathrm{~m})$, the maximum $\mathrm{CO}$ concentration was approximately $2.5-4.0 \mathrm{ppb}$. The contaminants were uniformly mixed by turbulence in the mixed layer since the 

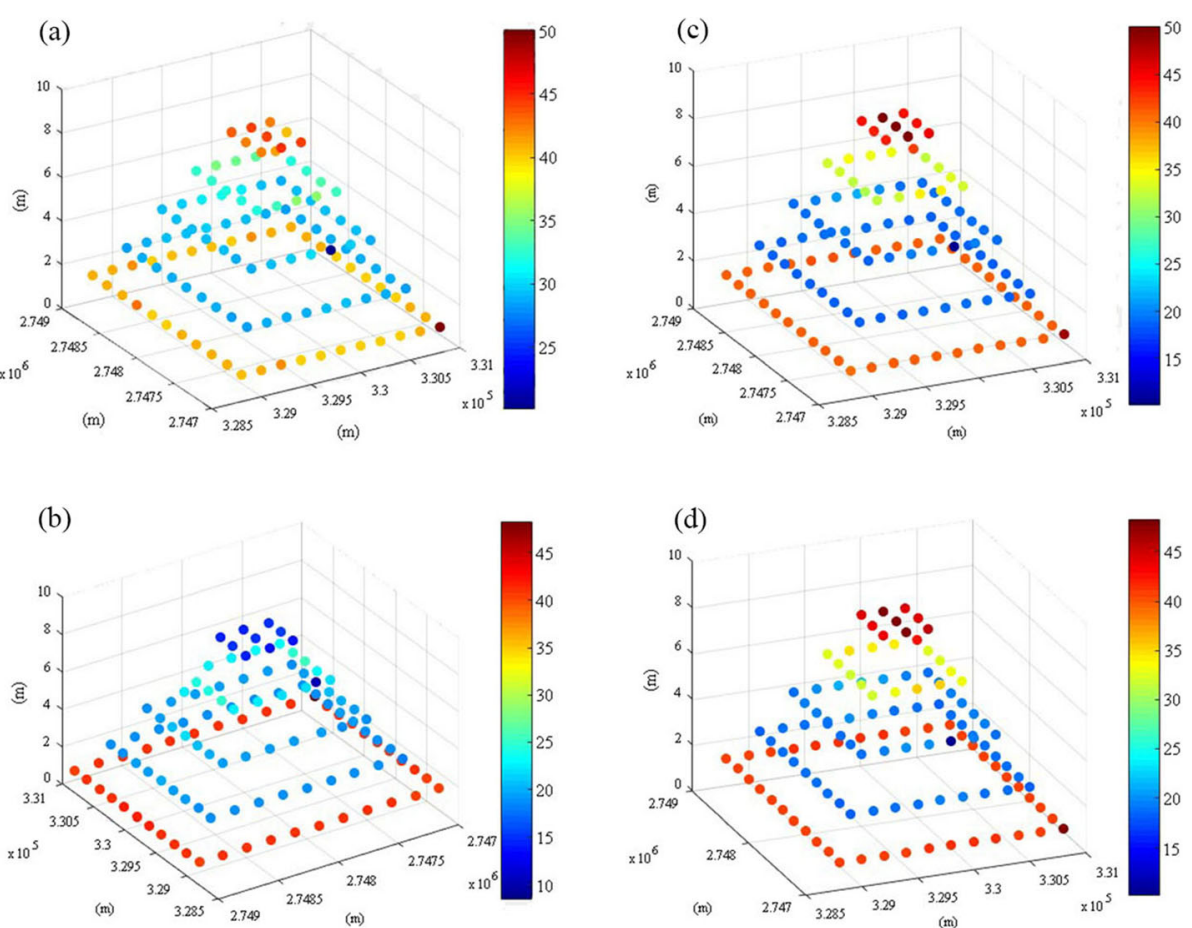

Fig. $10 \mathrm{PM}_{25}$ spatial distributions during rush hours: a on weekday afternoons; $\mathbf{b}$ on weekday mornings; c on weekend afternoons; $\mathbf{d}$ on weekend mornings

concentration decreased as the mixing height increased as the contaminants were transported and diluted. In contrast, the low mixing layer height promotes the formation of atmospheric heavy pollution processes. Atmospheric stability has obvious effect on the simulation results. Therefore, the correlation coefficient of the meteorological conditions affects the simulated $\mathrm{CO}$ concentration, the mixed layer height, the wind speed, and wind direction, as shown in Fig. 11. The traffic volume data are from TANEEB. They offer real-time traffic information from a camera. The daily traffic volume in hours was collected by Electronic Toll Collection. From the simulation results, it was found that the concentration of various pollutants in the tunnel increased with the increase in the number of vehicles. The concentration of various pollutants was higher in the tunnel when the number of vehicles entering the tunnel was greater. The correlation coefficient between volume and concentration in the tunnel increased with the increasing number of vehicles entering the tunnel, as shown in Fig. 12a. The correlation coefficients between $\mathrm{CO}, \mathrm{PM}_{2.5}, \mathrm{NO}$, and $\mathrm{SO}_{2}$ concentrations and the number of vehicles are $0.99,0.94,0.89$, and 0.89 , respectively.

\section{Validation against the measurement data}

The comparison of the modeled concentrations with the monitored concentrations is a process termed verification $[18,20]$. Model verification investigates the discrepancies between modeled and measured concentrations, which can arise as a result of the presence of inaccuracies or uncertainties in model input data and/or modeling and monitoring data assumptions [36, 37]. The following are examples of potential causes of such discrepancies: estimates of background pollutant concentrations, meteorological data uncertainties, traffic data uncertainties, model input parameters, and overall limitations of the dispersion model [38]. In the CFD simulation and calculation, it was necessary to check the correlation coefficient. The monitored concentration data were sourced from the EPA. The sampling positions were located in one safety passing bay and the inlet/outlet of the tunnel. In the CALINE4 model, we compared the measured and predicted concentrations near the Toucheng intersection. In addition, it is difficult to measure the vertical pollutant concentration near a high level without UAVs. Therefore, a UAV with a sensor hanging system was used to monitor the levels of pollutants, and it was good to verify the prediction data along the vertical direction. Figure $12 \mathrm{~b}$ indicates that the correlation coefficient of CFD was 0.9374 . This is very close to the simulation data; a reason for this might be that indoor concentrations from the inside tunnel are more controllable.

In this study, we compared the measured and predicted concentrations, for example, the concentrations of $\mathrm{NO}, \mathrm{CO}$, and $\mathrm{PM}_{2.5}$ that were predicted near the Toucheng intersection. On a weekday, the highest $\mathrm{NO}$ concentrations were measured at $8 \mathrm{am}$, as shown in Fig. 13. 

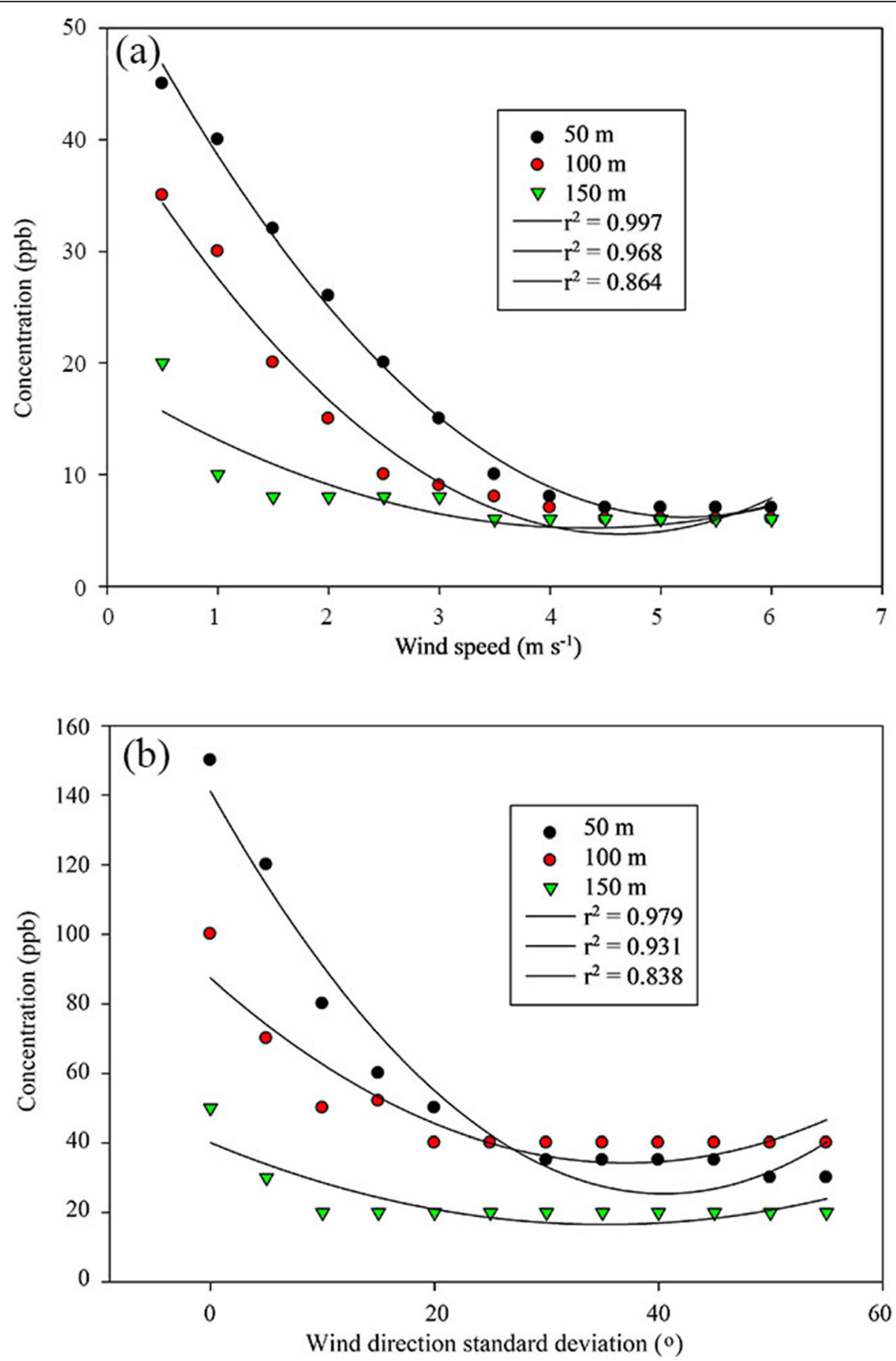

Fig. 11 a Relationship between wind speed and CO concentration; b the relationship between wind direction standard deviation and CO concentration

Likewise, NO levels were higher on weekdays than on weekends, especially during the rush hour in the morning. Provincial roads No. 2 and No. 9 are industrial roads, with trucks passing through this area to transport products. There are two peaks over the course of $24 \mathrm{~h}$. The highest concentration is at $8 \mathrm{am}$. Additionally, the $\mathrm{NO}$ concentration was approximately 0.08 to $0.12 \mathrm{ppm}$.
The other peak is at $6 \mathrm{pm}$. Furthermore, the NO concentration was approximately 0.06 to $0.1 \mathrm{ppm}$. The simulated values correspond to the measured values, except in the afternoon. The difference in observed and simulated NO concentrations due to the terrain where the highway is located in the valley. The trend is similar between the observed and simulated NO concentrations 

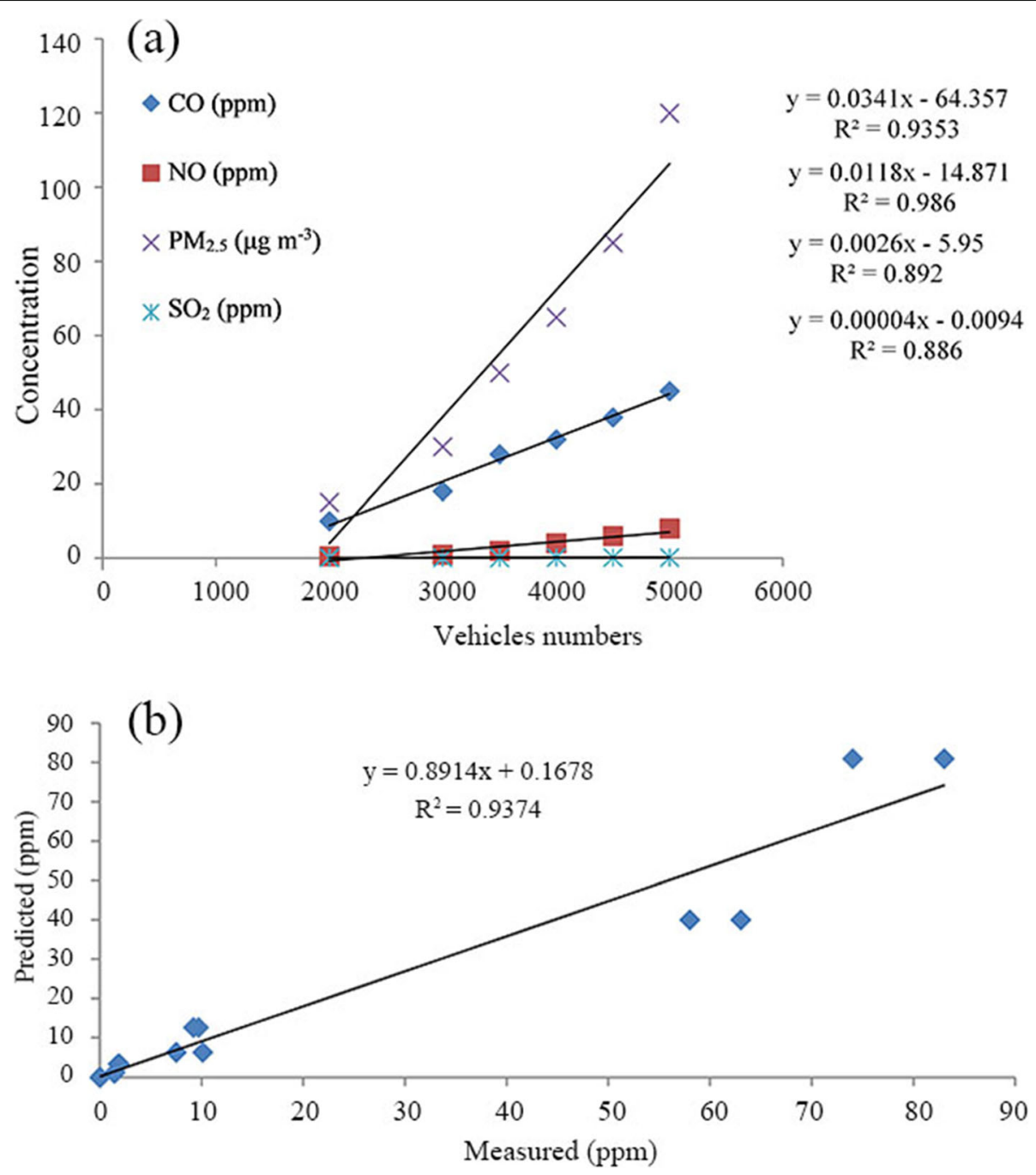

Fig. 12 a Exhaust pollutant and vehicle numbers; $\mathbf{b}$ correlation coefficient of CFD

due to the vehicle trend. On a weekday, the highest $\mathrm{CO}$ concentrations, $0.06-0.10 \mathrm{ppm}$, were measured at $8 \mathrm{am}$. The concentration was between 0.08 and $0.12 \mathrm{ppm}$ on the weekend during rush hour in the morning. The values from the simulation differ significantly from the measured values at night. This result was similar to a previous study by Dhyani and Sharma [15]. This could be because vehicle heat fluxes increase as there is an increment in traffic volumes, providing higher vertical dispersion and dilution. $\mathrm{PM}_{2.5}$ concentrations at the measurement locations during weekdays and weekends are shown in Fig. 13. The highest concentration of $\mathrm{PM}_{2.5}$ is in the morning. It has two peaks in Weekday. The predicted data exceed the measurement at the Toucheng intersection.

In addition to the above comparative analysis, this model was tested using NMSE and FB to understand the statistical performance. The analysis results of the performance of the model data are shown in Tables 3 and 4. The simulation results demonstrate the satisfactory performance of the CALI NE4 and show that the model could be used for exposure assessments in future environmental impact assessments. Hence, according to statistical analysis of simulation model performance for air quality prediction, the values (e.g., FB, and NMSE) are well within the acceptable limits. It could be proposed that the CALINE4 model for the prediction of vehicular emissions in traffic congestion areas is valid.

\section{Conclusions}

This study validated the methodology using NMSE, FB, and correlation coefficient to understand the statistical performance. The CALINE4 model and CFD are suitable to estimate traffic-related pollutant concentrations, and a flexible UAV with a sensor hanging system can be chosen to monitor the levels of pollutants. The results show that the correlation coefficient and the other 


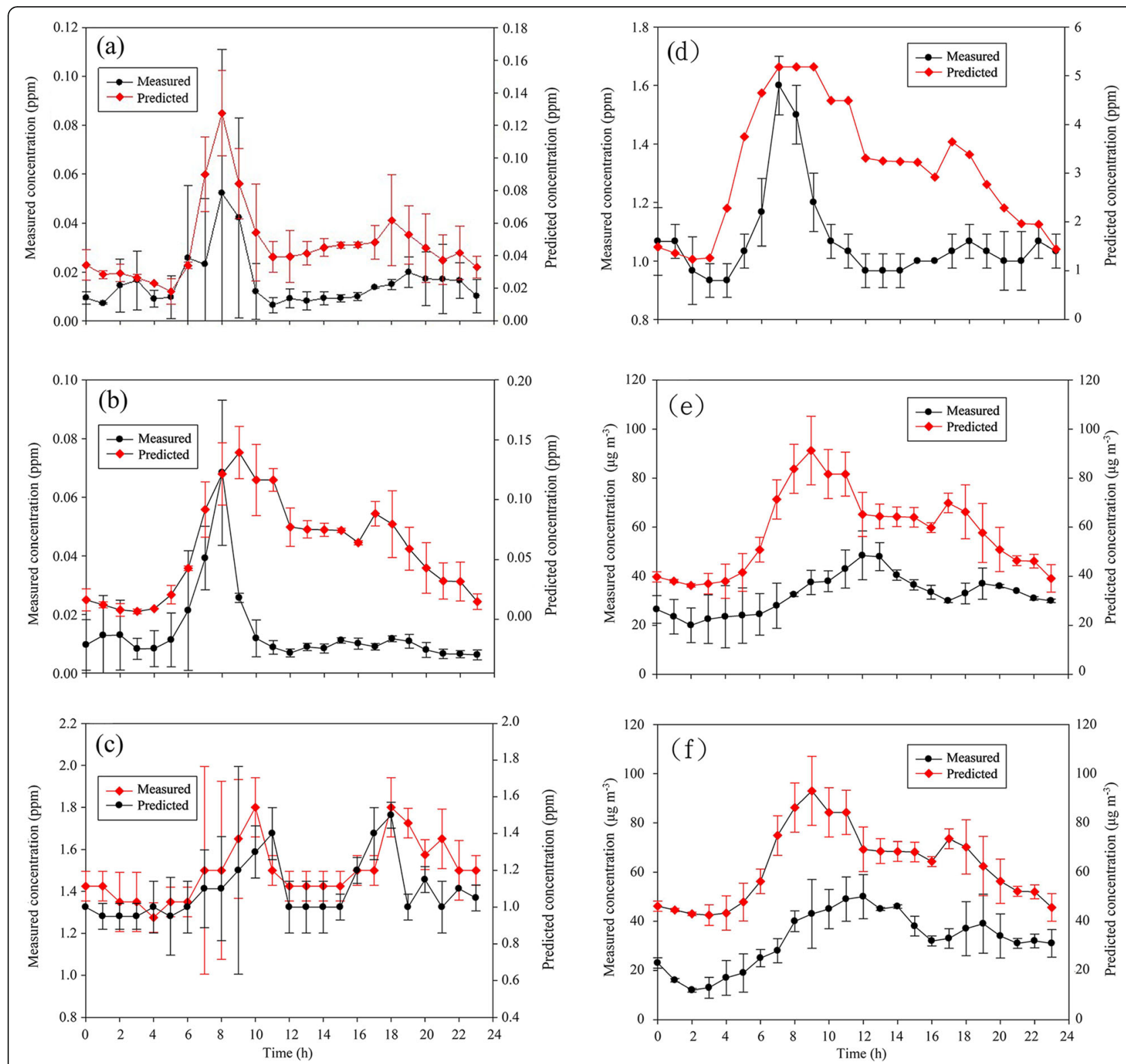

Fig. 13 Comparison of measured and predicted data: a NO on weekdays; b NO on weekends; c CO on weekdays; d CO on weekends; e PM 2.5 on weekdays; $\mathbf{f} \mathrm{PM}_{2.5}$ on weekends

Table 3 Statistical performance of the CALINE4

\begin{tabular}{llllllll}
\hline $\begin{array}{l}\text { Statistical performance } \\
\text { indicators }\end{array}$ & $\begin{array}{l}\text { NO } \\
\text { Weekend }\end{array}$ & CO & $\mathbf{P M}_{\mathbf{2 . 5}}$ & $\begin{array}{l}\text { NO } \\
\text { Weekday }\end{array}$ & CO & PM $_{2.5}$ & $\begin{array}{l}\text { Acceptable } \\
\text { range [14] }\end{array}$ \\
\hline NMSE & 0.4 & 0.09 & 0.08 & 0.2 & 0.2 & 0.09 & NMSE $\leq 0.5$ \\
FB & 0.1 & 0.09 & -0.1 & 0.15 & 0.15 & -0.1 & $-0.5 \leq F B \leq 0.5$ \\
Correlation coefficient $\left(r^{2}\right)$ & 0.66 & 0.50 & 0.51 & 0.74 & 0.67 & 0.50 & $r^{2}>0.5$ \\
\hline
\end{tabular}


Table 4 Performance evaluation of CALINE4 model

\begin{tabular}{lll}
\hline & NMSE & FB \\
\hline This study & $0.09-0.4$ & $-0.1-0.2$ \\
Dhyani et al. [14] & $0.05-1.8$ & $-1.2-0.2$ \\
Dhyani and Sharma [15] & 0.09 & 0.3 \\
\hline
\end{tabular}

parameters are in a reasonable range, despite the traffic in this area being complicated. In the Hsuehshan tunnel, the vehicle speed is $40 \mathrm{~km} \mathrm{~h}^{-1}$ when the fan is opened on the weekend, and $\mathrm{SO}_{2}, \mathrm{CO}, \mathrm{NO}$, and $\mathrm{PM}_{2.5}$ concentrations are mainly distributed in the tunnel outlet, with concentrations ranging from 0.001 to $0.004,4.0$ to 9.0 , 0.7 to $1.8 \mathrm{ppm}$, and 40 to $60 \mu \mathrm{g} \mathrm{m}^{-3}$. On weekdays, $\mathrm{SO}_{2}$, $\mathrm{CO}, \mathrm{NO}$, and $\mathrm{PM}_{2.5}$ concentrations are mainly distributed in the tunnel outlet, with concentrations ranging from 0.001 to $0.003,2$ to $6,0.36$ to $1.3,0.36$ to $1.08 \mathrm{ppm}$, and 20 to $55 \mu^{-3} \mathrm{~m}^{-3}$. At the Toucheng Intersection, the simulated $\mathrm{PM}_{2.5}$ concentrations located at 9.0, 7.0, 5.0, and $3.0 \mathrm{~m}$ were approximately 50 to $74 \mu \mathrm{g} \mathrm{m}^{-3}$. On holidays, the UAV monitoring concentrations were 40 to 45 , 25 to 30,20 to 25 , and 40 to $43 \mu \mathrm{g} \mathrm{m}^{-3}$ in the morning. On the weekend, the highest pollutant emission rate comes from Highway No. 5. The correlation coefficients between traffic volume and $\mathrm{CO}, \mathrm{PM}_{2.5}, \mathrm{NO}$ and $\mathrm{SO}_{2}$ concentrations were $0.99,0.91,0.89$, and 0.89 , respectively.

The results provide information on vehicular exhaust emissions in a long tunnel and along a $2 \mathrm{~km}$ length of the highway, including information on air quality together with information on the three-dimensional spatial distribution of $\mathrm{PM}_{2.5}$ concentrations. These data are useful for transportation planners working towards a traffic management plan. Meanwhile, this study provides a reference method to be used for environmental impact assessments for long tunnels and areas prone to traffic jams. For future research, CFD could simulate volatile organic compounds in indoor environments to evaluate the relationships between volatile organic compound use and health. Compared with the traditional measurement pollutant concentration method, UAVs with sensor hanging systems have many advantages in measuring vertical pollutants, thus they address the limitations of future studies.

\section{Acknowledgements}

The authors wish to thank the students of Air Pollution Control Laboratory, National llan University for their assistance in monitoring and sampling.

\section{Authors' contributions}

Shin Yu conceptualized the study, conducted laboratory works, provided the statistics, processed the data and fulfilled the analysis, wrote the draft. Chang Tang Chang provided software and performed the analysis supervision, draft writing supervision. Chih Ming Ma performed the analysis supervision, final manuscript writing and editing. All authors read and approved the final manuscript.

\section{Funding}

This work was supported by Grant MOST105-2221-E-562-002-MY3.

Availability of data and materials

All data generated or analyzed during this study are available upon request.

\section{Declaration}

Competing interests

The authors declare they have no competing interests.

\section{Author details}

${ }^{1}$ Department of Environmental Engineering, National Ilan University, Yilan 260007, Taiwan. ${ }^{2}$ Department of Cosmetic Application and Management, St. Mary's Junior College of Medicine, Nursing and Management, Sanxing Township 266003, Taiwan.

Received: 31 January 2021 Accepted: 12 July 2021

Published online: 28 July 2021

\section{References}

1. Chuang HC, Ho KF, Lin LY, Chang TY, Hong GB, Ma CM, et al. Long-term indoor air conditioner filtration and cardiovascular health: a randomized crossover intervention study. Environ Int. 2017;106:91-6.

2. Carslaw DC, Priestman M, Williams ML, Stewart GB, Beevers SD. Performance of optimised SCR retrofit buses under urban driving and controlled conditions. Atmos Environ. 2015;105:70-7.

3. Saini J, Dutta M, Marques G. A comprehensive review on indoor air quality monitoring systems for enhanced public health. Sustain Environ Res. 2020; 30:6.

4. Chuang KJ, Lin LY, Ho KF, Su CT. Traffic-related $P M_{2.5}$ exposure and its cardiovascular effects among healthy commuters in Taipei, Taiwan. Atmos Environ-X. 2020;7:100084.

5. Chen RY, Ho KF, Hong GB, Chuang KJ. Houseplant, indoor air pollution, and cardiovascular effects among elderly subjects in Taipei, Taiwan. Sci Total Environ. 2020;705:135770.

6. Polidori A, Arhami M, Sioutas C, Delfino RJ, Allen R. Indoor/outdoor relationships, trends, and carbonaceous content of fine particulate matter in retirement homes of the Los Angeles basin. J Air Waste Manage. 2007;57: 366-79.

7. Kaur S, Nieuwenhuijsen MJ, Colvile RN. Fine particulate matter and carbon monoxide exposure concentrations in urban street transport microenvironments. Atmos Environ. 2007;41:4781-810.

8. Fruin S, Westerdahl D, Sax T, Sioutas C, Fine PM. Measurements and predictors of on-road ultrafine particle concentrations and associated pollutants in Los Angeles. Atmos Environ. 2008:42:207-19.

9. Huertas Jl, Prato DF. CFD modeling of near-roadway air pollution. Environ Model Assess. 2020;25:129-45.

10. Okokon EO, Yli-Tuomi T, Turunen AW, Taimisto P, Pennanen A, Vouitsis I, et al. Particulates and noise exposure during bicycle, bus and car commuting: a study in three European cities. Environ Res. 2017;154:181-9.

11. Campagnolo D, Cattaneo A, Corbella L, Borghi F, Del Buono L, Rovelli S, et al. In-vehicle airborne fine and ultra-fine particulate matter exposure: the impact of leading vehicle emissions. Environ Int. 2019;123:407-16.

12. Barnes MJ, Brade TK, MacKenzie AR, Whyatt JD, Carruthers DJ, Stocker J, et al. Spatially-varying surface roughness and ground-level air quality in an operational dispersion model. Environ Pollut. 2014;185:44-51.

13. Batterman SA, Zhang K, Kononowech R. Prediction and analysis of nearroad concentrations using a reduced-form emission/dispersion model. Environ Health-Glob. 2010;9:29.

14. Dhyani R, Singh A, Sharma N, Gulia S. Performance evaluation of CALINE 4 model in a hilly terrain - a case study of highway corridors in Himachal Pradesh (India). Int J Environ Pollut. 2013;52:244-62.

15. Dhyani R, Sharma N. Sensitivity analysis of CALINE4 model under mix traffic conditions. Aerosol Air Qual Res. 2017;17:314-29.

16. Baik JJ, Kim JJ, Fernando HJS. A CFD model for simulating urban flow and dispersion. J Appl Meteorol Clim. 2003;42:1636-48.

17. Tominaga $Y$, Stathopoulos T. Turbulent Schmidt numbers for CFD analysis with various types of flowfield. Atmos Environ. 2007;41:8091-9. 
18. Wang XF, Conboy K, Cawley O. "Leagile" software development: an experience report analysis of the application of lean approaches in agile software development. J Syst Software. 2012;85:1287-99.

19. Qin DC, Guo B, Zhou J, Cheng HM, Chen XK. Indoor air formaldehyde (HCHO) pollution of urban coach cabins. Sci Rep-UK. 2020;10:332.

20. Cardozo JHH, Sanchez DFP. An experimental and numerical study of air pollution near unpaved roads. Air Qual Atmos Hlth. 2019;12:471-89.

21. Santiago JL, Martilli A, Martin F. CFD simulation of airflow over a regular array of cubes. Part l: three-dimensional simulation of the flow and validation with wind-tunnel measurements. Bound-Lay Meteorol. 2007;122: 609-34.

22. Llaguno-Munitxa M, Bou-Zeid E, Hultmark M. The influence of building geometry on street canyon air flow: validation of large eddy simulations against wind tunnel experiments. J Wind Eng Ind Aerod. 2017;165:115-30.

23. Bari S, Naser J. Simulation of airflow and pollution levels caused by severe traffic jam in a road tunnel. Tunn Undergr Sp Tech. 2010;25:70-7.

24. Bhautmage U, Gokhale $S$. Effects of moving-vehicle wakes on pollutant dispersion inside a highway road tunnel. Environ Pollut. 2016;218:783-93.

25. Zhang $\mathrm{CH}$, Kovacs JM. The application of small unmanned aerial systems for precision agriculture: a review. Precis Agric. 2012;13:693-712.

26. Hien VTD, Lin C, Thanh VC, Oanh NTK, Thanh BX, Weng CE, et al. An overview of the development of vertical sampling technologies for ambient volatile organic compounds (VOCs). J Environ Manage. 2019;247:401-12.

27. Hildmann H, Kovacs E. Review: Using unmanned aerial vehicles (UAVs) as mobile sensing platforms (MSPs) for disaster response, civil security and public safety. Drones. 2019;3:59.

28. Gu QJ, Michanowicz DR, Jia CR. Developing a modular unmanned aerial vehicle (UAV) platform for air pollution profiling. Sensors-Basel. 2018;18:4363.

29. $\mathrm{Ma} \mathrm{CM}$, Hong $\mathrm{GB}$, Chang $\mathrm{CT}$. Influence of traffic flow patterns on air quality inside the longest tunnel in Asia. Aerosol Air Qual Res. 2011;11:44-50.

30. Thompson JF, Soni BK, Weatherill NP, editors. Handbook of grid generation. 1st Boca Raton: CRC Press; 1998.

31. Rhys-Tyler GA, Legassick W, Bell MC. The significance of vehicle emissions standards for levels of exhaust pollution from light vehicles in an urban area. Atmos Environ. 2011:45:3286-93.

32. Burr ML, Karani G, Davies B, Holmes BA, Williams KL. Effects on respiratory health of a reduction in air pollution from vehicle exhaust emissions. Occup Environ Med. 2004;61:212-8.

33. Peng ZR, Wang DS, Wang ZY, Gao Y, Lu SJ. A study of vertical distribution patterns of $\mathrm{PM}_{2.5}$ concentrations based on ambient monitoring with unmanned aerial vehicles: a case in Hangzhou, China. Atmos Environ. 2015; 123:357-69.

34. Cheng YH, Liu ZS, Chen CC. On-road measurements of ultrafine particle concentration profiles and their size distributions inside the longest highway tunnel in Southeast Asia. Atmos Environ. 2010;44:763-72.

35. He LY, Hu M, Zhang YH, Huang XF, Yao TT. Fine particle emissions from onroad vehicles in the Zhujiang Tunnel, China. Environ Sci Technol. 2008;42: 4461-6.

36. Kastner-Klein P, Plate EJ. Wind-tunnel study of concentration fields in street canyons. Atmos Environ. 1999;33:3973-9.

37. Sagrado APG, van Beeck J, Rambaud P, Olivari D. Numerical and experimental modelling of pollutant dispersion in a street canyon. J Wind Eng Ind Aerod. 2002;90:321-39.

38. El-Harbawi M. Air quality modelling, simulation, and computational methods: a review. Environ Rev. 2013;21:149-79.

\section{Publisher's Note}

Springer Nature remains neutral with regard to jurisdictional claims in published maps and institutional affiliations.

Ready to submit your research? Choose BMC and benefit from:

- fast, convenient online submission

- thorough peer review by experienced researchers in your field

- rapid publication on acceptance

- support for research data, including large and complex data types

- gold Open Access which fosters wider collaboration and increased citations

- maximum visibility for your research: over $100 \mathrm{M}$ website views per year

At BMC, research is always in progress.

Learn more biomedcentral.com/submissions 